\title{
Religion and Morality in Hobbes
}

\author{
EDWIN CURLEY
}

\section{Prelude on Religion and Morality}

In "Religion and the Queerness of Morality,"1 George Mavrodes has argued that a religious view of the world is a necessary presupposition of morality, that morality makes sense only on a religious view. "Religion" here means at least a generic theism, incorporating doctrines common to Judaism, Christianity, and Islam. Specifically, unless you believe that you have been created by a God who will judge your actions in this life and mete out punishments and rewards in an afterlife, you will not find it rational to recognize and honor moral obligations. Moral obligations frequently require us to forego certain this-worldly goods. Telling the truth is (in most circumstances at least) a moral obligation, but often it carries a cost which seems to make it imprudent. Why should we pay that cost unless there is a system of divine justice, involving otherworldly goods, which can make up for the deficiencies of human justice? Mavrodes' position is a counterfactual version of that taken by Hobbes' Fool, who says in his heart that there is no God, and that, since there is no God, we have no reason to be just. ${ }^{2}$ Mavrodes says that if the Fool were right about there not being a God, he would also be right about the reasonableness of morality.

Mavrodes canvasses various ways a philosopher might try to show that moral obligations make sense even on a nonreligious view of the world, giving most attention to a line of argument he finds in Kurt Baier, but which has, as he recognizes, roots in Hobbes. So Hobbes appears, in his argument, as representative of a way you might defend morality, even if you did not believe in a theistic religion. I think this is typical of the way philosophers who have not specialized in the study of Hobbes think of him. ${ }^{3}$ The view of Hobbes held by most "philosophers in the street" - that is, philosophers who know enough

This essay is the final version of a paper I presented at the conference in honor of Gregory Kavka entitled "Rationality, Commitment, and Community," held at the University of California at Irvine on Feb. 10-12, 1995. In the interim I presented versions of it at the University of Colorado at Boulder and at Dartmouth College. By now I am indebted to more people for their comments than I can clearly recall, but those who stand out in my memory are David Gauthier, Brian Skyrms, Steve Darwall, Margaret Wilson, Walter Sinott-Armstrong, and Barbara Tovey. 
about Hobbes to have some view about what might be important in his work but are not Hobbes specialists - is very like that held by many of Hobbes' contemporaries: that he was an atheist (or perhaps merely a thorough religious skeptic), but, in any case, someone in rebellion against the dominant religious tradition of his times, and so a suitable precursor for modern secularists.

\section{Philosophers in the Street vs. Hobbes Specialists}

It may come as a surprise to the philosopher in the street to know how frequently, in this century, Hobbes scholars have taken a different approach to Hobbes. It began, I think, with an influential article by A. E. Taylor, ${ }^{4}$ arguing that Hobbes was a deontologist whose moral theory could not be adequately understood without recognizing his theological commitments. Howard Warrender took a similar line in his book on Hobbes, as did F. C. Hood. ${ }^{5}$ Then there was a lull in theistic interpretation, as people took time to digest the work of Taylor and Warrender. David Gauthier, in his book on Leviathan, ${ }^{6}$ conceded that Hobbes was a theist but argued that his moral and political theory is independent of any theistic suppositions. Jean Hampton took a similar line, ${ }^{7}$ as did Gregory Kavka. ${ }^{8}$

Now we are seeing a new wave of theistic interpretation, represented by the books of A. P. Martinich and Sharon Lloyd, ${ }^{9}$ both of which argue that Hobbes was a theist and that recognizing this fact about him is essential to understanding his moral and political theory. Martinich holds an extreme version of this line: he thinks Hobbes was not merely a theist but a Christian, and an orthodox one at that (specifically, a Calvinistic Anglican). Lloyd's view is more moderate. She avoids controversy about Hobbes' orthodoxy, on the plausible ground that the term "orthodox" is too ill defined to be useful in discussion ${ }^{10}$ and does not try to identify Hobbes with any particular denomination. But she does think that he was a Christian - indeed, that he had "an unshakable belief in the truth of the Christian religion," that he was trying to make a version of Christian belief appear reasonable to modern man, and that seeing that this was his project is essential to understanding Leviathan. ${ }^{11}$

So you have, broadly speaking, two schools of thought among the specialists, one holding that Hobbes was a theist, but that it does not matter, because his moral and political philosophy is independent of his religious beliefs, the other holding that he was a theist, and that this matters a great deal, that you cannot properly understand his moral and political thought without recognizing its religious component. I hold what seems to be a minority view among the specialists. ${ }^{12}$ I think Hobbes was probably an atheist, but that at a minimum he was deeply skeptical about Christianity, and about theism in general, and that seeing that is essential to understanding Leviathan. I see Hobbes as one member of an underground movement, which also included Spinoza and Hume, 
whose purpose was to subvert the dominant religion of their culture and to free people from the authority of the priests and their sacred texts. So I think that with respect to this issue the philosopher in the street is nearer the mark than the majority of recent Hobbes specialists seem to be. I have argued this elsewhere, ${ }^{13}$ without, so far as I know, persuading anyone yet. But here I intend to have another go at it, to try to show that a theistic interpretation of Leviathan is not plausible on the evidence, and that we miss something important about Hobbes if we do not see this.

\section{Methodology}

Most English-language writers who specialize in the history of early modern philosophy these days concentrate on the history of metaphysics and epistemology and leave the study of early modern moral and political philosophers to those who specialize in moral and political philosophy, people who frequently do not have broader interests in the history of the early modern period and are often political theorists first and historians second. ${ }^{14}$ This fact about the discipline can have unfortunate consequences.

It is not that the people who write books on Hobbes' moral and political philosophy are not capable of producing work that makes a major contribution to our understanding of Hobbes' thought. The work of Gregory Kavka, whom we are honoring in this volume, is a splendid example to show that they can. I yield to no one in my admiration for his contributions to Hobbes scholarship. He did as much to help me understand Hobbes as any other scholar I have read (and much more than most). But he did not claim to approach Hobbes as an historian would: He focused on certain aspects of the text of Leviathan and had little to say about others (particularly those parts of the work dealing with religious issues); he made only occasional use of Hobbes' other works; and as he himself said, he "largely ignored" the historical context of the work, aiming to provide "a model of how a classic text can be used to contribute to contemporary debate." 15 I think he achieved that goal, which is no small accomplishment. I think, in addition, that he was unduly modest about his historical skills. He did write about Hobbes in a way which not only made him an interesting contributor to contemporary debates but also was extremely useful to the historian trying to figure out what the best reading of the text is. His brilliance enabled him to transcend the limitations of his official methodology.

That said, one of my goals in this discussion is to argue that there is also value in a more historical approach, and that such an approach need not make Hobbes any less interesting for contemporary philosophers. ${ }^{16}$ The methodological principles which will guide this study are familiar enough: Looking at the historical context of the author's work is important; so is looking at the contemporary reception of the work, looking at other works by the philosopher, looking at 
biographical data and correspondence, and looking at variant versions of the text. I suppose many people would be prepared to grant these principles, even if they are not prepared to act on them. What needs argument here, I assume, is the claim that if you do not attend to these maxims of historical scholarship, you may miss something really interesting about Hobbes.

One of the great difficulties in understanding Leviathan is that you need to be alert to the presence of irony in this work. Irony is often a difficult thing to be sure about. Hearing its presence requires not taking the text at face value, and many interpreters are understandably reluctant to do that. But some readers of Leviathan seem to me to be tone deaf when it comes to hearing clear notes of irony. Recognizing irony requires having some sense of what it was possible for an author of a certain period to think and to say. I hope to show that an understanding of the Renaissance and Reformation debates about religion - combined with a knowledge of other matters which seem mainly to interest historians - may help you to detect irony in Leviathan, and (if your interpretation of that text has been unduly influenced by the recent secondary literature) alter your perception of this masterwork. Theistic interpretations of Hobbes often seem to assume that it was just not possible for anyone in seventeenth-century Europe to be as critical of Christianity as I think Hobbes was, and that if Hobbes had been that much at odds with the dominant religion of his time and place, he would have had to keep quiet about it, since he could not have found a receptive audience for his critique. To write that critically of Christianity, it will be said, would have alienated his readers and undermined his political project of persuading people that the sovereign needed, and was entitled, to absolute obedience. A little history should clear us of these illusions.

\section{Reflections on Anticlericalism}

Theistic interpreters of Hobbes will probably concede that he was profoundly anticlerical. They could hardly deny it. Hobbes may have had dear friends among the clergy, men like Mersenne and Gassendi, but he did not like the clergy as a class. Here is an anecdote Aubrey tells in his biography of Hobbes:

Mr. Edmund Waller said to me, when I desired him to write some verses in praise of him [Hobbes], that he was afraid of the churchmen. He quoted Horace - "Incedo per ignes suppositos cineri doloso." ["I tread on fire still smouldering underneath deceptive ash." Odes 2.1] - that what was chiefly to be taken notice of in his elegy was that he, being but one, and a private person, pulled down all the churches, dispelled the mists of ignorance, and laid open their priest craft. ${ }^{17}$

Waller knew Hobbes pretty well, as the recent edition of Hobbes' correspondence makes clear, ${ }^{18}$ and his judgment about what was to be taken notice of in Hobbes' elegy deserves our attention. 
Now it may be said that to be anticlerical is not necessarily to be irreligious; to be critical of the Christian clergy, for example, is not necessarily to reject the religion they represent. Martinich makes this point. ${ }^{19}$ I concede the point. Indeed, I made it myself in the article Martinich criticizes, citing the example of Milton. ${ }^{20}$ Now I would add the examples of Erasmus and Luther, both of whom had scathing things to say about the clergy of their day. There is an entertaining illustration of this in the dialogue Erasmus wrote just after the death of Pope Julius II, ${ }^{21}$ called Julius Excluded from Heaven.

In this work Erasmus imagines Julius presenting himself at the gates of heaven and being denied admission by Saint Peter. (Julius has neglected to bring the Keys to the Kingdom with him.) At the end of the dialogue, Saint Peter says to Julius's "genius" (i.e., his guardian angel): "Are you the one who stirred him up to such atrocious crimes?"

Julius's genius replies: "I did hardly anything; he was so eager in his vices that even with wings I could hardly have followed him."

To which Saint Peter responds: "Well, I'm not surprised that we get so few candidates for admission, when monsters like this are in charge of governing the church. But perhaps the common people may be curable - or so I conjecture from the fact that because of the mere empty title of pope, they gave honor to such a filthy piece of garbage as this." 22

Erasmus is also quite critical of the clergy in his better-known work, The Praise of Folly, though in that work - which, unlike Julius Excluded from Heaven, he acknowledged having written - he is careful not to name any of the popes he mocks. ${ }^{23}$ His idea is that if the objects of his satire are not named, they can take offense only by admitting that they are guilty of the offenses he criticizes. There may be some doubt about Erasmus's orthodoxy, ${ }^{24}$ but I would not question his commitment to Christianity. (We will have an example from Luther later.)

That conceded, I think it is difficult psychologically to sustain a faith in Christianity, or any other organized religion, and at the same time reject the official representatives of that religion as thoroughly corrupt and disreputable. If you are a Christian, in the early modern period at least, one of the things you are apt to believe is that God revealed himself to man through Christ, and that the Church is the vehicle through which that revelation has been preserved and propagated. After the Reformation you may have some doubts about just which church is that vehicle, but if you come to regard that church's clergy as thoroughly corrupt, and your faith is not shaken, you will at least suffer what we now call "cognitive dissonance," a certain tension in your beliefs which is difficult to live with, and which, when resolved, may not be resolved in favor of the faith.

Hobbes himself makes a point very like this in his discussion of religion in Part I of Leviathan when he writes: 
For seeing all formed religion is founded at first upon the faith which a multitude hath in some one person, whom they believe not only to be a wise man, and to labour to procure their happiness, but also to be a holy man, to whom God himself vouchsafeth to declare his will supernaturally, it followeth necessarily, when they that have the government of religion shall come to have either the wisdom of those men, their sincerity, or their love suspected, or that they shall be unable to show any probable token of divine revelation, that the religion which they desire to uphold must be suspected likewise; and (without the fear of the civil sword) contradicted and rejected..$^{25}$ ( $\mathrm{L}$ xii, 24, my emphasis)

Hobbes seems to go further here than I would. He says that disillusionment with the clergy must shake your faith in the religion they profess; I claim only that it may do so. ${ }^{26}$ But perhaps Hobbes' point is more epistemological than psychological: not that it is a necessary law of human nature that all who suspect the clergy will suspect the religion the clergy represent, but that they ought to, given the grounds they have for belief in the religion. I leave this interpretive issue undecided.

Hobbes goes on, after this passage, to list various things which take away the clergy's reputation for wisdom, for sincerity, for love, and for having a divine calling. If they enjoin belief in contradictory statements, fail to practice the moral doctrines they teach, are detected in private ends, and are unable to perform miracles or make true prophecies, their credit will suffer. He concludes by commenting that the sole cause of change in religion is "unpleasing priests, and those not only amongst Catholics, but even in that church which hath presumed most of reformation" (L xii, 32). So even the most reformed of churches has its share of unpleasing priests. Perhaps this is one passage Waller had in mind when he said that Hobbes had "pulled down all the churches."

\section{Anticlerics and Antichristians}

There are anticlerics and anticlerics. Machiavelli, like Erasmus, is also strongly anticlerical. I suggest that Hobbes is closer to Machiavelli than to Erasmus, and that Machiavelli is no Christian. There are important differences between Hobbes and Machiavelli, of course, but the similarities are interesting enough to be worth pursuing.

You will not know much about Machiavelli's anticlericalism if you have read only The Prince, because the criticism of the clergy in that work is very mild. The Prince was not published in Machiavelli's lifetime, but it was dedicated to (and evidently sent to) Lorenzo de' Medici, whose uncle had just ascended the throne of Saint Peter as Leo X (successor to Julius II). The discussion of the clergy comes primarily in chapter $\mathrm{xi}$, where Machiavelli discusses ecclesiastical states; it appears first as what I take to be ironic praise: only the rulers of ecclesiastical states can maintain their power without either ability (virtù) or luck (fortuna), because they are "sustained by ancient religious institutions, which have been 
sufficiently strong to maintain their rulers in office however they live or act."27 Then, after a cool, non-judgmental analysis of the political policies of Alexander VI (pope from 1492 to 1503) and Julius II (pope from 1503 to 1513), and of how they used money and military force to increase their power, Machiavelli concludes by expressing some optimism about Leo: "His Holiness Pope Leo has found the Papacy very powerful indeed; and it is to be hoped that, just as his predecessors made it great by their military activity, he, by his goodness and countless other virtues, will make it both very great and worthy of reverence" (my translation and emphasis). The implication is that the papacy was not worthy of reverence under Alexander and Julius. Machiavelli had gone into exile after the republican government he served was overthrown. In The Prince he is hoping he can get a place in the new political order by making himself useful to the Medici, who have replaced the republican government. Mild criticism of Alexander and Julius will be acceptable, and a little flattery of Leo will not be amiss.

In The Discourses, which also were not published during Machiavelli's lifetime but may have reached members of the Medici family indirectly, ${ }^{28}$ the criticism of the Church is much sharper. ${ }^{29}$ Machiavelli holds the Church responsible for the decline of both religion and morality in Italy:

The wicked examples presented by the papal court have caused the whole of Italy to lose all piety and all religious devotion ... Just as respect for religion has a whole range of beneficial consequences, so contempt for religion has a whole range of evil consequences. We Italians owe this much to our Church and our clergy: they have made us irreligious and wicked. ${ }^{30}$

Notice that Machiavelli anticipates the Hobbesian principle that disrespect for the clergy leads to disrespect for the religion they represent. And Machiavelli is no friend of the clergy as he knows them in the Italy of his day.

Does he also reject their religion? I think he does, though this is a matter of dispute. He certainly does not reject it openly and unequivocally, and he is not hostile to all religion as such. He thinks a religion of the right kind is a good thing, because it is very useful politically. So in the Discourses he credits Numathe second of the kings of Rome and successor to Romulus, the founder of Rome - with having done foundational work comparable in its importance to that of Romulus by establishing a religion in Rome:

The Romans of his day were completely wild, not domesticated; he wanted to train them to live a sociable life and to practice the arts of peace. So he turned to religion, because it is essential for the maintenance of a civilized way of life, and he founded a religion such that for many centuries there was more fear of God in Rome than there has ever been anywhere else. Such piety was of considerable assistance whenever the senate or one of Rome's great leaders undertook any enterprise. (I, xi, p. 114)

One reason religion was valuable to the Romans was that it made them very fearful of breaking oaths, and this was good both for civil order and for mili- 
tary discipline. But the Roman religion also served the public good by encouraging men to do great deeds, by defining the supreme good as "boldness of spirit, strength of body, and all the other qualities that make men redoubtable" (II, ii, p. 168). The Roman religion did not make men completely domesticated; rather, it taught them to save their savagery for the enemies of the state.

Two points need emphasis here. Though religion does, in Machiavelli's eyes, serve the interests of the rulers, enabling them to get their proposals accepted by adding the luster of divine sanction to their authority (I, xi, p. 115), it does not serve only their interests. In Rome religion also served the interests of the community as a whole. The Roman state which this religion was so instrumental in forming and preserving was the most durable and powerful republic ever known, the best historical example of the best kind of government, selfgovernment. Machiavelli sees republican government (in the Roman sense) as the only stable form of government in which people are free; for him, liberty is a very important value. He does not mind that this religion was not a true religion, and that its acceptance involved deception of the people by their rulers. Numa claimed that his actions were authorized by the gods: he "pretended," as Machiavelli puts it, "to be on friendly terms with a nymph who advised him on everything before he made recommendations to the people" (I, xi, p. 115). Machiavelli does not for a moment credit those claims. For that matter, neither did his source, the Roman historian Livy. (Cf. Livy, I. 18-21.) Hobbes reminds us of this story from Livy in chapter xii, paragraph 20 of Leviathan, where he adds other examples (from Islam and the religion of the Incas) in support of the general proposition that the first founders of "gentile commonwealths" (or "heathen religions," as the marginal summary says) always claim divine authority for their edicts. ${ }^{31}$

Though Machiavelli thinks the right kind of religion is a good thing, it does not appear that he thinks Christianity is the right kind of religion. In some respects Christianity is like the religion of pagan Rome: it provides divine authority for the actions of human rulers and gives people reason to think that if they commit a crime and escape the power of human justice, they are still not home free. So far, Christianity is a good thing. But Machiavelli does not seem to think that it teaches the right virtues. He says in the Discourses:

Our religion, by contrast [with the religion of ancient Rome], glorifies men who are humble and contemplative, rather than those who do great deeds. In fact, it regards humility, self-abasement, and contempt for worldly goods as the supreme virtues ... It is true our religion requires that you be strong, but it wants you to demonstrate your strength by undergoing suffering without complaint, rather than by overcoming resistance. This set of values, it would seem, has turned the men of our day into weaklings and left them unable to defend themselves against the ravages of the wicked. The wicked have no difficulty in handling their fellow men, for they know the average individual wants rather to endure their blows than to strike back, for he hopes to go to heaven. (II, ii, pp. 168-9) 
Notice that Machiavelli speaks of Christianity here as "our religion." Elsewhere in the same chapter he says that "our religion has taught us the truth and the right way to salvation" (p. 168). Some scholars infer that Machiavelli was a sincere Christian. ${ }^{32}$ I do not. It seems clear from both The Prince and The Discourses, that, if Machiavelli believed that Christianity teaches these virtues as the proper route to heaven, he does not believe in practicing them. He certainly does not preach those virtues; he may not be the amoralist he is reputed to be, but he did not get his reputation for nothing.

Machiavelli does provide a way out of the conclusion that he rejected Christian ethics. He makes a distinction in the Discourses between Christianity as commonly taught and Christianity properly interpreted:

Although it seems we have all been made effeminate, and God himself allows injustice to flourish, it is of course the fault of the sinful nature of mankind, which has caused them to interpret the teachings of our religion as suits their lazy temperament, and not as brave men would have done. For if they had taken into account the fact that our religion allows us to praise and defend our homeland, they would have realized that if we are religious we ought to love and honor our country, and to prepare ourselves to be the sort of people who will be capable of defending it. (p. 169; my emphasis)

I emphasize that last phrase because I think that if you reflect on the kind of person Machiavelli thinks it is necessary to be in order to be capable of defending your homeland, and then reflect on the teachings of Christianity, you will find Machiavelli's "interpretation" of Christianity too implausible to be credible as an interpretation. ${ }^{33}$

For authentically Christian theorists in the sixteenth century, it was hard to see how to combine Christianity, which preaches nonresistance to evil (Matt. 5:39), with political authority, which inherently involves the use of force to resist evil. Luther, for example, wrestling with this problem in his treatise On Secular Authority, concluded that it was not impossible, but still a rare and difficult thing, to be both a Christian and a prince at the same time. ${ }^{34}$ Similarly Erasmus advises his Christian prince to "do violence to no one ... tolerate injuries rather than avenge them at great cost to the state [even if] your empire is likely to be reduced to some extent," and to abdicate rather than defend his kingdom by violating justice, incurring much bloodshed, or damaging the cause of religion. ${ }^{35}$

For authors whose Christian commitments are less clear, the Gospel teaching was a serious ground of objection to Christianity. Sometime in the $1590 \mathrm{~s}$ Jean Bodin, who was at least nominally a Catholic, wrote a dialogue, the Colloquium heptaplomeres, in which the representatives of various religious points of view appear: a Catholic, a Lutheran, a Calvinist, a Jew, a former Christian converted to Islam, a defender of natural religion, and a skeptic. ${ }^{36}$ The dialogue form makes it a matter of speculation which party (if any) represents Bodin's point of view. Bodin did not publish this dialogue even posthumously, and it did not appear in print until the nineteenth century, but it had considerable clan- 
destine circulation before that. Seventeenth-century authors who knew it often regarded it as an attack on Christianity, ${ }^{37}$ perhaps because of the critique of Christian ethics that Bodin puts in the mouth of some of his non-Christian interlocutors. A central theme of the critique is that it is contrary to human nature, and hence impossible, to adhere consistently to the injunction to return good for evil. 38

For the most part Hobbes' Leviathan does not use the dialogue form. Instead he uses a strategy like Machiavelli's. He advocates a pagan morality and then alleges that it is Christian. His second law of nature requires

That a man be willing, when others are so too, as far forth as for peace and defence of himself he shall think it necessary, to lay down this right to all things, and be contented with so much liberty against other men, as he would allow other men against himself. (L xiv, 5; my emphasis. Cf. xv, 36.)

This prescription to divest yourself of your natural right to all things is, as I emphasize, conditional on others being willing to do the same. No sooner has Hobbes said this than he has the cheek, as I would call it, to identify this principle with the Golden Rule, as if the Golden Rule taught that we should do unto others as we can reasonably expect them to do unto us. ${ }^{39}$

In the Renaissance there was a tendency, in reaction against the complexity some would say, absurd subtlety - of scholastic theology, to reduce Christianity to its moral teachings. Erasmus is representative of this tendency, which is one reason Luther is so hostile to him in De servo arbitrio. ${ }^{40}$ There was a battle going on in the sixteenth century over the soul of Christianity. I take it that if the moral teachings of Jesus do not constitute the essence of Christianity, they are at least essential to it. So if you reject moral teachings which are central to the Gospel message, you reject the religion. ${ }^{41}$

It seems to me that both Machiavelli and Hobbes teach a doctrine fundamentally incompatible with Christian ethics, and that it is, therefore, a mistake to regard them as Christians. They both, of course, present their doctrine as an interpretation of Christian ethics. But I do not take that claim very seriously. In the period in which they were writing, someone in fundamental disagreement with Christian teaching could hardly be open about his disagreement with any safety. Machiavelli and Hobbes represent one way in which it was possible for a Renaissance humanist to resolve the conflict between Christianity and classical culture, a way very different from the way Erasmus chose. If we are not conscious of the historical context in which Hobbes is working, we may take much too seriously his assimilation of his second law of nature to the Golden Rule.

\section{Hobbes and Spinoza on Miracles}

Let us come back to another favorite passage of mine from Aubrey's biography, which reports Hobbes' reaction to reading Spinoza's Theological-Political 
Treatise (1670). Waller had sent Lord Devonshire (Hobbes' patron) a copy of the work and asked him what Hobbes thought of it. Hobbes replied cautiously to Lord Devonshire, citing Matthew 7:1 ("Judge not that ye be not judged"), and more informatively to Aubrey: "He told me he [Spinoza] had out thrown him [Hobbes] a bar's length, for he durst not write so boldly." ${ }^{42}$ Theistic interpreters of Hobbes tend not to like this remark. Hood, for example, casts doubt on Aubrey's reliability as a reporter. Martinich asks how we can hope to determine what Hobbes might have meant by this. Perhaps Hobbes just admired Spinoza's prose style.

An earlier article of mine ${ }^{43}$ asked what Hobbes might have meant, recognizing that any answer must be conjectural, but arguing that if we find Hobbes and Spinoza taking up the same topics, and if we find Spinoza consistently taking a bolder position than Hobbes on those topics, we have some reason both to trust Aubrey's reporting and to suppose that Hobbes might have wished that he had felt free to make such claims himself. We can never be certain what Hobbes meant - and that may be one reason why some interpreters of Hobbes will not venture into this swamp - but I suggest that if there are enough affinities, and they seem deep enough, we may properly conclude that Spinoza, in some respects, represents what Hobbes himself saw as a logical development of his thought.

In that earlier article I took up three topics: prophecy, miracles, and the authority of Scripture, each of which Hobbes discusses, in what seems a rather skeptical vein, in Part III of Leviathan, and each of which Spinoza takes up more fully (and I would say, much more boldly) in the Theological-Political Treatise. These topics are closely connected: a prophet, in traditional theology, is the initial vehicle of divine revelation, an intermediary between God and man; miracles constitute one of the criteria for distinguishing true prophets from false ones; and Scripture is the record of the revelation the prophets conveyed. These three topics are central to the claim of Christianity to be based on a divine revelation.

I will not repeat what I said in my earlier article. But I would like to enlarge on one of its themes and then add a new one to the list. The old theme is the issue of miracles. Hobbes' discussion of miracles is complex, and we cannot go into all its subtleties, but he concludes that because "mankind [are apt] to give too hasty belief to pretended [i.e., alleged] miracles, there can be no better, nor I think any other, caution, than that which God hath prescribed [e.g., in Deut. 13:1-5] ... that we take not any for prophets that teach any other religion than that which God's lieutenant . . . hath established" (L xxxvii, 13). When Deuteronomy was written, "God's lieutenant" was Moses. When Hobbes was writing, God's lieutenant was "the head of the Church," whose identity, of course, varied with the identity of the church (and in England, the identity of the monarch or other secular ruler). So that person, and the doctrine she ${ }^{44}$ has established, are to be consulted 
before we give credit to a pretended miracle or prophet. And when that is done, the thing they pretend to be a miracle, we must both see it done, and use all means possible to consider whether it be really done or no; and not only so, but whether it be such as no man can do the like by his natural power, but that it requires the immediate hand of God. And in this also we must have recourse to God's lieutenant ... So also if we see not, but only hear tell of a miracle, we are to consult the lawful Church, that is to say, the lawful head thereof, how far we are to give credit to the relators of it. (Ibid.)

Hobbes does not exclude the possibility of a contemporary miracle and generally implies the existence of bona fide miracles in the past, but he sets demanding criteria for accepting contemporary claims that a miracle has occurred, and he leaves all doubtful cases to the decision of the sovereign. He emphasizes human gullibility and the possibility of priestly deception in a way which foreshadows Hume. Why, if reports of present-day miracles are untrustworthy, should we credit reports of past miracles, when it is so much more difficult to investigate claims about past miracles?

Still, Spinoza takes a more radical position: miracles in the strict sense are a logical impossibility; in the strict sense a miracle would be a violation of a law of nature; but the laws of nature are an expression of the power of God, God's decrees concerning nature, so any occurrence contrary to those laws would be an occurrence contrary to the will of an omnipotent being, which is absurd. Spinoza acknowledges a loose sense of the term "miracle," in which it signifies an occurrence which we, at a certain point in the development of human knowledge, cannot understand in terms of the laws of nature. But acceptance of miracles in this sense is merely recognition of human ignorance, which cannot be made the foundation of any knowledge of God.

Now it may be said that many perfectly good Christians have been skeptical about many alleged miracles, even when those miracles are alleged to support (some form of) the Christian religion. Luther is a case in point. In his Appeal to the Ruling Class of German Nationality he first rejects the use of miracles to support the authority of the pope: "If an authority does anything against Christ, it is due to the power of the Antichrist and of the devil, even if that authority makes it rain and hail miracles and plagues. Miracles and plagues prove nothing, especially in these latter days of evil, for specious miracles of this kind are foretold everywhere in Scripture." Later Luther criticized, as one of the abuses of the Roman Church, the establishment of "extra-parochial chapels and churches" as the goal of pilgrimages. He thinks pilgrimages are just one of many corrupt methods the clergy have found to get money out of the laity:

It is useless to argue that miracles are seen in these places, for the Evil Spirit can also work miracles, as Christ declared (Matthew 24:24). If they got to work in all seriousness and forbade things of this kind, the miracles would soon cease . . these things are indications of great unbelief among the people; for if their faith were as it should be, they would find everything needful in their own churches ... Each bishop is only thinking 
how he can start one of these pilgrimages in his own province, not caring whether the people believe and live as they should ... [their aim] is to draw crowds and cause money to flow. ${ }^{45}$

It is dangerous, I think, for Christian authors to acknowledge that people are easily taken in by miracle stories, particularly if in doing so they attribute corrupt motives to the Christian clergy. They may encourage more doubts than they intend to. The admission - indeed, insistence - that human gullibility and greed have operated even within the Christian world simply feeds the doubts of those humanists whose acquaintance with classical historians, and with the uses religion was put to in the pagan world, has already encouraged them to be suspicious. ${ }^{46}$ If Christianity is to be a convincing exception to the general run of religions, its clergy ought to be more virtuous than that.

\section{Hobbes and Spinoza on Natural Law}

One of Spinoza's more revolutionary conclusions in the Theological-Political Treatise is that God cannot be a lawgiver. In Chapter iv, on the strength of an argument similar to his argument concerning miracles, Spinoza contends that if God were a lawgiver (in the relevant sense of the term "law"), he would have to prescribe to men rules that they are capable of either obeying or disobeying, as it seems good to them, taking into account the possible consequences of obedience or disobedience. But one thing which God, in spite of his omnipotence (or rather, precisely because of his omnipotence), cannot do is to prescribe laws in that sense of the term. For a law, in that sense, is a command, that is, an expression of the will of the commander. And if God wills, say, that Adam not eat the apple, then Adam will not eat the apple, indeed, will not be able to eat the apple. When we speak of law in connection with God, the only thing we can coherently mean is a necessary truth about how things actually behave, and must behave; we cannot mean a command that they are capable of disobeying. To suppose otherwise is to confuse the power of God with the power of human monarchs. ${ }^{47}$

I conjecture that this may be one of the things Hobbes found interesting in Spinoza. The doctrine does, later in Spinoza's work, lead to some rather Hobbesiansounding conclusions about the status of obligations in the state of nature. In the Theological-Political Treatise (xvi, 9) Spinoza concludes that the law of nature "prohibits nothing except what no one desires and what no one can do: not disputes, not hatreds, not anger, not deception; without qualification, it is not averse to anything which appetite urges." This is certainly reminiscent of the doctrine of Chapter xiii, paragraph 13, of Leviathan: that in the war of all against all which characterizes the state of nature "nothing can be unjust. The notions of right and wrong, justice and injustice, have there no place. Where there is no common power, there is no law; where there is no law, no injustice." 
Students of Hobbes' reception will know that many of his readers found this statement troubling.

Leibniz is a case in point. He wrote Hobbes a letter in $1670,{ }^{48}$ inviting him to clear his theory of the consequences which certain unsympathetic interpreters had attached to it:

If anyone ... applied your theory of the complete licence which exists in the state of nature to the dealings which take place between all the citizens of various republics, he would, I think, fall far wide of your own opinion ... For you recognize that ... given the existence of a ruler of the world, men cannot live in a pure state of nature outside all republics, since God is the common monarch of all men. So when some people accuse your hypotheses of licentiousness and impiety, they are wrong. Having ... always understood your theories [in this way], I confess that they have kindled a great light in my mind. ${ }^{49}$

You might conclude from this that Leibniz was the originator of the TaylorWarrender thesis, but I think he is being slightly disingenuous here.

In the same year Leibniz also wrote to Jacob Thomasius in rather different terms, reporting that he had "recently seen an article ... in which you treated according to its deserts an intolerably licentious book on the liberty of philosophizing." Leibniz is referring here to Spinoza's Theological-Political Treatise, which argues, among other things, for freedom of thought and expression. He continues,

The author seems to follow not only Hobbes' politics, but also his religion, which he has outlined so adequately in his Leviathan, a work monstrous even in what its title suggests. ${ }^{50}$ For Hobbes, in a whole chapter of Leviathan [xxxiii], has sown the seeds of that very smart critique which this bold man carries out against Sacred Scripture. ${ }^{51}$

Because Spinoza's rejection of natural law, and of the associated concept of God as a lawgiver, is clear and unequivocal, Leibniz's claim that Spinoza follows Hobbes' politics as well as his religion suggests that he does not take the theistic natural law theory of Leviathan at face value. I suggest that in the letter he wrote to Hobbes Leibniz is trying to draw Hobbes out on the question of the relation between God and natural law. So far as we know, Hobbes never replied to Leibniz's letter - so he did not endorse the Taylor-Warrender interpretation of his natural law theory when Leibniz gave him the opportunity to do so.

In Chapters xiv and xv of Leviathan, Hobbes enumerates some nineteen "laws of nature." Given what he has said in Chapter xiii, the appearance of laws of nature at this point is anomalous. At the end of Chapter xv Hobbes either clarifies the situation or muddies the waters, depending on how you take it:

These dictates of reason men use to call by the name of laws, but improperly; for they are but conclusions or theorems concerning what conduceth to the conservation and defence of themselves, whereas law, properly, is the word of him that by right hath command over others. But yet if we consider the same theorems, as delivered in the word of God, that by right commandeth all things, then are they properly called laws. ${ }^{52}(\mathrm{~L} \mathrm{xv}, 41)$ 
Now Taylor and Warrender ${ }^{53}$ regarded this passage as extremely important, because they saw the last sentence as canceling the apparently anarchic implications of Chapter xiii, and as saying, in effect, "If you are an atheist, you can only regard these so-called laws as hypothetical imperatives; it is only if you are a theist that you can see that they really are laws, which impose a genuine obligation independently of any human legal system."

I, on the other hand, hold that at heart Hobbes does not think his laws of nature are properly called "laws," in the sense defined by this passage, that he regards them as a (very special) kind of hypothetical imperative. I hold that he is (probably) an atheist (or at least a thorough skeptic about theistic religions), who is content to permit his theistic readers to interpret his laws of nature as laws in the strict sense, but who, for his part, regards them as being "merely" a very special kind of hypothetical imperative.

Why? For one thing Hobbes does not seem to attach as much importance to the last sentence of paragraph 41 in Chapter $\mathrm{xv}$ as he ought to, on the TaylorWarrender interpretation. He omits it from the Latin Leviathan. He also ignores it when he paraphrases the final paragraph of Chapter $x v$ in paragraph 8 of Chapter xxvi. And if this should be dismissed as a mere argument from silence, in Chapter xxvi he denies that the laws of nature are actually laws until a commonwealth has been established and the sovereign commands obedience to them. ${ }^{54}$

These textual and biographical data are not decisive. No such information ever is. They are simply interesting data, which may add up to something, if there are enough of them, and which may prompt us to ask related questions, which may have interesting answers. What would Hobbes have thought about Spinoza's argument that God cannot be a lawgiver? Could that argument be one of the acts of boldness Hobbes admired in Spinoza?

Perhaps Hobbes approved of the argument as he found it in Spinoza; perhaps not. One reason for doubt is that, as Spinoza states his argument, it depends on the theological doctrine that in God, will and intellect are identical. It is not obvious what that means or why a theist must accept that assumption. In reformulating Spinoza's argument earlier in this section I deliberately avoided introducing that assumption, because it seemed to me obscure and inessential. Hobbes may have found it both obscure and essential.

But Hobbes did have the materials for his own argument to the same conclusion. He never states that conclusion - but he does state premises from which that conclusion can easily be derived. The Hobbesian argument, like Spinoza's, would rely crucially on a definition of "law":

(1) Law in general is not counsel, but command; nor a command of any man to any man, but only of him whose command is addressed to one formerly [i.e., by a prior act of consent] obliged to obey him. ( $\mathrm{L} \mathrm{xxvi,2)}$ 
Consider next the definition of the term "command":

(2) Command is where a man saith do this, or do not this, without expecting other reason than the will of him that says it. (xxv, 2)

In both these passages Hobbes seems to be treating laws and commands as prescriptions from one human being to others. Let us take that apparent limitation to be inessential. (Otherwise we get too quickly to the conclusion that there cannot be a divine law.) From his definition of command Hobbes draws the following conclusion:

(3) He that commandeth pretendeth thereby his own benefit; for the reason of his command is his own will only, and the proper object of every man's will is some good to himself.

From this we may conclude that

(4) If there is such a thing as a divine law (in the prescriptive sense of "law"), it must be a command which God issues for the purpose of securing his own benefit.

I then observe that, according to Hobbes,

(5) God has no ends (L xxxi, 13). ${ }^{55}$

But if God cannot have as his object any good to himself, then on Hobbesian principles

(6) There can be no such thing as a divine law (in the prescriptive sense of the term "law").

The fact that this argument is available to Hobbes - and is indeed a fairly easy deduction from premises he explicitly adopts within a relatively short stretch of Leviathan - encourages me to think that one of the things Hobbes liked about the Theological-Political Treatise was its conclusion that God cannot be a lawgiver.

\section{Sifting out Disinformation}

So far, if I am right, we have the following result: Hobbes was an anticleric who thought that anticlericalism entailed rejection of the religion the clerics represent; he did, in fact, reject central elements of Christian moral teaching; he was also quite skeptical about the miracle stories on which the claim of the Christian Scriptures to be a record of divine revelation is based; and there are grounds for thinking that he rejected the Christian conception of God as a lawgiver, who would distribute punishments and rewards in an afterlife. Other scholars may read these passages differently than I do, particularly where my reading involves, 
not just reporting what Hobbes says, but inference from what he says. ${ }^{56}$ But suppose, for the moment, that I am right. Does this entail that Hobbes was, in a strict sense, an atheist, someone who denies that there is any legitimate sense in which it can be said that there is a God?

Of course not. If I have Spinoza right, he was a Hobbesian in all the relevant respects, and I do not think (contrary to what Martinich, for example, assumes) that Spinoza was an atheist. I think Spinoza is sincere when he says that he believes in God. It is a very different God from the God of Abraham, Isaac, Jacob, and Jesus. Spinoza's God is an impersonal set of principles immanent in the universe: it has no intellect, no will, no purposes, no affects like love, hate, or anger. But Spinoza's austere God is evidently, for him, an object of love, and when he says that the love of this God is man's highest good, I think he means it. So I consider Spinoza a religious thinker of a very unconventional sort. I see no sign of this kind of philosophical religiosity in Hobbes. It is possible that Hobbes was a kind of nondenominational theist, who believed in God, without believing in any of the major religions of his day. But I see no reason to think so.

A full discussion of this issue would require discussion of various passages in which Hobbes affirms a belief in God and offers arguments for God's existence. This is a subject I have written about elsewhere, ${ }^{57}$ and I have no desire to repeat myself. But I would like to reprise one theme of that discussion, with an embellishment or two.

Hobbes does not claim merely to be a theist. He claims to be a Christian, and, indeed, an Anglican who "favored the episcopal side."58 If we attempt to defend a compromise position according to which Hobbes was a theist but not specifically a Christian, we must discount some, at least, of the things he says about his religious views. The only question is, how much? If, when we say that Hobbes was disingenuous in his avowals of conventional religious views, we impute some moral fault to Hobbes - say, dishonesty, or cowardice - then the compromise position is also involved in that imputation (though not to the degree that a more radical interpretation would be). I do not myself think that there would be any moral fault in Hobbes' being disingenuous on this subject, given the circumstances in which he was operating. Whatever fault is to be found lies with those who persecute unorthodox opinions. But theistic interpreters frequently act as if they were defending Hobbes' honor. I reject the suggestion that his honor is at issue here and insist that, if it were, it would also be at issue when Hobbes is read as a nondenominational theist.

In 1642 Hobbes wrote, in De cive, that man can know that there is a God by the light of nature (ii, 21) or by natural reason (xiv, 19; xv, 14). He does not actually say there what arguments reason can use to come to know that God exists, but it seems fair to suppose that he would have used some form of the argument from a first cause, since that is the argument he uses in The Elements 
of Law (I, xi, 2), written two years earlier than De cive, and in Leviathan (xi, 25), which Hobbes was beginning to write around the time of the second edition of De cive in 1647. De cive is a work Hobbes published and is well known to Hobbes scholars.

In 1642 Hobbes also wrote, but did not publish, a work called An Examination of Thomas White's De mundo. White was a friend of his who had written a cosmological treatise attempting to reconcile the new science with the foundations of the Christian religion. ${ }^{59}$ Hobbes' critique of White lay in the Bibliothèque Nationale for some three hundred years, unrecognized as a Hobbesian work, until Jean Jacquot and Harold Whitmore Jones identified it and made it available. ${ }^{60}$ Though this work is a major find, knowledge of it seems to have been slow to penetrate the world of Hobbesian scholarship. Perhaps because it is primarily a scientific treatise and the interests of most Hobbes scholars lie elsewhere, I know only one recent writer on Hobbes who takes notice of it: David Johnston in his book The Rhetoric of Leviathan. ${ }^{61}$

What is interesting about this work, for our purposes, is that in it Hobbes takes quite a different line about arguments for the existence of God than he takes in his published works of the period. One thing White had claimed to do was to demonstrate the existence of God by positing God as a necessary first cause to explain the existence of motion. This is a familiar enough line of argument, one which, judging by his published works, you might expect Hobbes to be sympathetic to. But in the Examination of White Hobbes contends that White's attempt is both unphilosophical and antireligious: unphilosophical because it shows a misunderstanding of the nature of demonstration to suppose that questions of existence or nonexistence are capable of demonstration (xxvi, 2 ); antireligious because the attempt to prove the articles of faith necessarily weakens both faith and religion (xxvi, 4). Rulers should not allow their subjects to claim to demonstrate such matters as the existence of God and the immortality of the soul. The attempt to prove such theses will only cause ordinary people to consider them false, "because those who wished them to be true could not demonstrate that they were" (xxvi, 6).

Indeed, there is an even greater danger: the philosopher who inquires into the nature and cause of motion may come upon some proposition now held by the Christian faith which seems to contradict something he has previously proven. He may be tempted to conclude that the Christian doctrine is false. The proper conclusion is that he does not understand in what sense it is true (xxvi, 7). But those who subject incomprehensible matters of divinity to their own metaphysical speculations almost inevitably come into conflict with Christianity at every step (xxviii, 3) - so it is best to avoid such speculation.

Hobbes' position in the Examination of White involves quite a strong form of fideism: not merely that the Christian faith requires belief in propositions inaccessible to human reason, but that it requires belief in propositions prima facie 
contrary to reason. Now it should be said immediately - and loudly and clearly, so that there can be no mistake - that there is nothing inherently atheistic or irreligious or un-Christian about adopting a fideism of this strength. Certainly there have been Christians whose faith I would not dream of questioning who have held similar positions. In this context Luther seems the most apt example. ${ }^{62}$ But a fideism this strong does seem surprising in an author capable of writing that men set "themselves against reason as oft as reason is against them" $(\mathrm{L} \mathrm{xi}, 21)$ and that enjoining belief in contradictory propositions takes away "the reputation of wisdom" and is "an argument of ignorance" (xii, 25).

The issue, though, is not whether a strong, antirationalistic fideism is inherently an irreligious view, or even whether it is credibly a Hobbesian view, but what explanation we can give of Hobbes' adoption of a strongly fideistic position in the Examination of White. Since Hobbes wrote this work during a period when he was repeatedly proclaiming in his published work that we can know by natural reason at least that God exists, it does not seem possible to explain the variation in position by postulating a change of view. My conjecture is that in the Examination of White Hobbes was experimenting with a position which he was tempted to adopt, as his way of dealing with the religious issue, when he wrote the foundational work which he thought his political philosophy demanded. But he hesitated to take such a strongly fideistic line in print, because he thought it too dangerous to represent Christian belief as irrational (rather than merely nonrational). I note that later, in De corpore (xxvi, 1), Hobbes does adopt a weaker form of fideism, according to which God's existence is merely not demonstrable by natural reason. Taking this line brought him grief enough from critics like Wallis. ${ }^{63}$ In the three major political works Hobbes takes a more traditional line. An author who is advocating unconventional views, at a time when such authors face the most fearsome of penalties, must make nice judgments about what it is safe to say.

This is, of course, merely a conjecture on my part. But it does seem to me that if theistic interpreters of Hobbes are going to give much weight to his claims that God's existence is knowable by natural reason, then they owe us some plausible explanation of the discrepancy between the published work and the unpublished work. So far I have not seen any of them attempt this task.

\section{Hobbes and His Audience}

One feature of Leviathan any interpreter must explain is the fact that so much of it is devoted to religious issues. This seems particularly puzzling if you think Hobbes is trying to show how morality can be reasonable on secularist principles. It will not do simply to say that Hobbes needs to cover his secularist tracks by pretending to take Christianity seriously, for the space he devotes to religious topics is out of all proportion to what would be needed for that. I gather that 
Sharon Lloyd wrote her book Ideals as Interests partly because she thought there was a glaring deficiency in the works of her most prominent recent predecessors: They made a good half of the text seem quite mysterious. ${ }^{64}$

Lloyd has an explanation for Hobbes' preoccupation with religious issues. She thinks he was a sincere Christian, who nevertheless rejected much of what passed for Christianity in his day, because it had been corrupted by the introduction of alien doctrines. So his project is to "rationalize" Christianity by paring away some of the irrational but illegitimate accretions. ${ }^{65} \mathrm{I}$ think there is some truth in that, but not enough. I take Hobbes' view to be that Christianity is probably a part of our culture which cannot, given human nature, be eliminated in the short term, and that given that fact, it is desirable to try to make it as undemanding as possible, both theologically and morally.

One reason Lloyd thinks my kind of reading of Hobbes ${ }^{66}$ must be wrong is that she thinks that Hobbes' readers were all committed Christians, that Hobbes knew this, and knew that it would be futile to try to discredit Christian belief. So even if Hobbes had not been a Christian, he would not have tried to write an anti-Christian tract:

In addition to his believing Christianity to be true, and a properly conceived Christianity to be invaluable in procuring civil obedience, Hobbes also recognized that his readers believed Christianity to be true, and thus he had a third reason for attempting to rationalize, rather than to discredit, Christian belief: Hobbes could never have hoped to succeed in persuading his audience to give up Christianity; so to have made an argument whose success depended upon their doing this would have been utterly vain. Had Hobbes tried to delegitimize Christianity itself, he would likely have been summarily dismissed and his theory ignored. ${ }^{67}$ (Her emphasis)

I think this supposes more homogeneity in Hobbes' audience than we are entitled to assume.

No doubt many of Hobbes' readers were so committed to Christianity that a frontal attack on their beliefs would simply have alienated them, would have caused Hobbes' book to be dismissed summarily and ignored. For that part of his audience Hobbes makes his criticism in an indirect way, which makes it possible for a committed Christian not to think that Christianity itself is under attack. ${ }^{68}$ For that part of his audience Hobbes' message is just that they should suspend judgment about much of what they have believed, that much of what seventeenth-century Christians believe is not essential to their religion, and that they should interpret their religion so that it is a support for, not a threat to, the social order. Hobbes does regard Christianity as a very dangerous religion, because some of its sacred texts appear to say that if there is a conflict between the will of God and the command of the sovereign, we must obey God rather than the sovereign. Much of Leviathan aims to defuse that threat by arguing that we have to rely on the sovereign to know what to treat as a sacred text, and how to interpret it. On Hobbes' preferred conception of Christianity, only two things 
are ultimately necessary for salvation: belief that Jesus is the Christ, and obedience to the laws of the civil society. ${ }^{69}$ This seems to me to take the minimalist tendencies I noted in Erasmus about as far as you can without passing into a view which no longer deserves to be called Christian. Indeed, if any Christian thought it crossed this line, she would not get an argument from me.

But there is, Hobbes believes, another part of his audience which is not so committed, which is at least uncertain about the theology, and not strongly inclined to accept the rather demanding moral requirements of Christianity. For this part of his audience Hobbes has a different message: he encourages their doubts about Christian theology, provides them with ammunition, and tries to give them a secular ground for practising those elements of Christian morality which are rationally defensible.

To see that there was such an audience out there, we might do various things. We might read Montaigne's Essais, and raise again the question whether Montaigne was as skeptical about Christianity as he has of ten seemed to subsequent readers. The current trend in Montaigne scholarship seems to favor reading him as a sincere fideist. ${ }^{70}$ But the older interpretation, stemming from Pascal, is still alive, and I think Pascal got Montaigne right: that his skepticism was deep, his fideism superficial, and his commitment to Christian values very suspect. $^{71}$

Since the example of Montaigne is a controversial one, we might do better to look at Bodin's Colloquium heptaplomeres, which clearly illustrates one consequences of the Reformation: the need to decide which version of Christianity is correct can easily lead to wondering whether any version of Christianity is the true religion, and from there to the question whether any historical religion is the true religion. Whatever doubts we may entertain about Bodin's personal convictions, it is at least the case that his dialogue forcefully raises all these questions. ${ }^{72}$

But perhaps the most helpful thing would be to read Pascal. After all, Hobbes wrote Leviathan in Pascal's Paris, as one of many expatriate Englishmen. Pascal certainly thinks that irreligion is widespread in his society. The famous wager argument (fragment 418, Krailsheimer; 233, Everyman) is addressed to someone who is unpersuaded by traditional arguments for the existence of God but remains open to an argument which appeals to his self-interest. What Pascal says, essentially, is this: let it be as uncertain as you like that God exists, as long as it is not impossible. Now consider what you stand to gain if you wager that God exists and win: eternal bliss in heaven. Compare that with your costs if you wager that God exists and lose: a few trivial pleasures. ${ }^{73}$ Surprisingly, Pascal does not actually call our attention to the fact that if we wager that God does not exist and lose, we lose very big: We go to hell for eternity. But I assume that that thought is in the subtext. ${ }^{74}$ His conclusion is that, however improbable it may be that God exists, we do best to believe that he does. This 
argument is clearly addressed to an audience Pascal thinks is quite prone to skepticism - and to a strong variety of skepticism at that, one which holds that God's existence is at best no more probable than his nonexistence, and, at worst, that his existence is highly improbable.

Hobbes' reply to the Fool ( $\mathrm{L} \mathrm{xv}, 4-8)$ has an interestingly similar structure. It is useful to point this out, if only to rebut those who find it anachronistic to use game-theoretic or decision-theoretic analyses in the interpretation of Hobbes. But it is also a helpful reminder when we are worrying about Hobbes' audience. He considers an opponent who has resolved the question of God's existence in the negative but is still uncertain how he ought to conduct his life. ${ }^{75}$ If there is no God to make up for the deficiencies of human justice, why should this man not pursue his own advantage without regard for justice, breaking his covenants when it seems conducive to his benefit, as it must sometimes be?

Hobbes' reply is that in the state of nature you are under no obligation to keep covenants that require you to perform first, trusting the other party to perform later; to do that would merely be to make yourself a prey to the ambition and

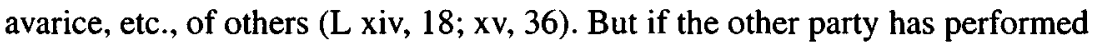
first, you no longer have any reason to fear that he will take advantage of your trust, and you ought to keep your covenant $(\mathrm{L} \mathrm{xiv}, 27) .{ }^{76}$ There may be circumstances in which it is highly improbable that you will pay any penalty for covenant breaking (particularly in the state of nature, where there is no sovereign to enforce covenants). You may, in those cases, expect significant gains if you opt for injustice. Still, it is not reasonable to order your life by trying to maximize your payoffs in that way. It will never be certain that you pay no penalty, and the costs of guessing wrong are disastrous. The price you may pay, if you are wrong, is exclusion from civil society. For if a civil society should form (or if an already formed civil society, of which you are not a member, should contemplate taking you in), the members of that society may learn of your unreliability; if they do, you cannot reasonably expect them to overlook it. And exclusion from civil society is the worst evil Hobbes can imagine. For Hobbes, hell is not other people, but the absence of other people, and of the benefits which cooperative living can bring.

Hobbes makes no assumption here about the probability of your acquiring a reputation for unreliability, except that it is not $0 .{ }^{77}$ What he does assume is that the disutility of exclusion is sufficiently great that no rational person will take even a very small risk of that outcome. ${ }^{78}$ Hobbesian prudence is highly risk averse when the disutility of the less favorable outcome is very great. It was Gregory Kavka, with his talk of disaster avoidance in the reply to the Fool, who helped me to see the similarity between Hobbes' reasoning and Pascal's. ${ }^{79}$ Kavka, of course, did not make the comparison with Pascal; that was not his style. 


\section{Religion and Morality in a Hobbesian World}

If the argument of this essay is correct, a Hobbesian world is the kind of world in which, as Mavrodes has argued, morality is queer, difficult to make sense of. There is no God, and no hope of reward or fear of punishment in an afterlife. So if we have prudential reasons to be moral, those reasons must rely only on the benefits and costs of this life.

Mavrodes' critique of modern-day Hobbesians is that their attempt to justify morality is fallacious. Their argument, as he presents it, begins with the assumption that

(A) It is in everyone's best interest (including mine) for everyone (including me) to be moral.

From this the modern-day Hobbesian is supposed to infer that

(B) It is in my best interest for everyone (including me) to be moral.

And from (B) it is concluded that

(C) It is in my best interest for me to be moral.

To this Mavrodes has two replies.

First, (C) certainly does not follow from (B). Even if, for the sake of argument, we grant (B), the most that would follow from (B) is

(C') It is in my best interest for me to be moral, provided everyone else is moral.

And the need to make this proviso betrays a fatal weakness in the argument. A defense of morality should not be conditional on such an unrealistic assumption.

Second, if (B) is to follow from (A), we must take (A) distributively rather than collectively (i.e., as meaning that each individual's interests are best served when everyone is moral, and not merely that the utility of the group as a whole is maximized, perhaps at the expense of certain individuals). But if we interpret (A) distributively, it is obviously false. Surely - assuming, of course, that we do not take into consideration possible costs and benefits in an afterlife - my best interests will be maximized in a world in which everyone else is moral and I act immorally when it suits me (e.g., when I can escape detection).

Now it seems to me pretty clear what Hobbes would say to this. Regarding the first point, he would not think that the principles of morality (his laws of nature) require us to make sacrifices of self-interest except when we have reasonable assurance of reciprocity (e.g., when there is a sovereign available to enforce covenants or when, in the state of nature, the other party has already performed). This is the point of the distinction between obligation in foro in- 
terno and obligation in foro externo $(\mathrm{L} \mathrm{xv}, 36)$. There is a substantive difference between the morality Hobbes is trying to justify and the morality Mavrodes expects secularists to justify. As far as actual conduct is concerned, Hobbesian morality does not require any more of us, in the state of nature, than an earnest endeavor to leave that state by establishing conditions under which we will have a reasonable assurance of reciprocity $(\mathrm{L}$ xiv, 5$)$. So Hobbes will concede to Mavrodes that he cannot justify promise keeping in the full range of cases in which Mavrodes might think it is obligatory, but he will not concede that he has to justify it in those cases, because he does not think that this is unconditionally an obligation. The differences between Hobbesian morality and Christian morality make it easier for Hobbes to justify that part of traditional morality which he thinks is valid.

As regards Mavrodes' second point, I think Hobbes would concede that (A) is false in its distributive interpretation. He must concede that, I think. For although it is plausible to hold that

(A') Everyone is better off in a world in which everyone follows the laws of nature than they would be in a world in which everyone pursues her own self-interest, without regard to those laws,

it does not follow from that fact that

(A") Everyone is better off in a world in which everyone follows the laws of nature than they would be in any other world.

Hobbes must, I think, concede to the Fool that he would be better off in a world in which everyone else followed the laws of nature while he pursued his own self-interest, without regard to the laws of nature, and without being detected. But if I have understood Hobbes correctly (i.e., if I am right in the Kavkaesque reading that I have given of Hobbes' reply to the Fool), the essential point is that, though each of us might be better off in a world in which everyone else obeyed the laws of nature while we pursued our own self-interest, than we would be in any world in which everyone followed the same rules (either the laws of nature or the laws of self-interest), it does not follow that it would be rational for us to act in the hope of living in such a world. Rationality does not consist in maximizing individual utility ${ }^{80}$ but in minimizing the risks of really bad outcomes. If we attempt to live according to the Fool's rules - follow the laws of nature when you think you must, pursue self-interest by disobeying those laws when you think you can (without detection) - we risk an appalling outcome: exclusion from civil society. So even though (A) and (A") are false, it is nonetheless rational for me to behave morally, as Hobbes understands that concept. The Fool identifies rationality, not with disaster avoidance, but with individual utility maximization. That's why he's a fool. 


\section{Notes}

1. George Mavrodes, "Religion and the Queerness of Morality," appeared first in $R a$ tionality, Religious Belief and Moral Commitment, ed. Robert Audi and William Wainwright (Ithaca: Cornell University Press, 1986), and subsequently in Louis Pojman's Philosophy of Religion (Belmont, CA: Wadsworth, 1994).

2. See Thomas Hobbes, Leviathan, ch. Xv, par. 4. I shall make all references to Leviathan hereafter in the text, in parentheses, by chapter and paragraph, following the system of paragraph numbering given in the edition of Leviathan which I published with Hackett in 1994, and abbreviating the title as L. Hobbes first published Leviathan in 1651 in English. One premise of my edition is that there are important differences between the English Leviathan and the Latin version which first appeared in 1668, in Amsterdam, during a period when there was a prohibition on reprinting the English Leviathan in England. My edition attempts to give an account of those differences.

3. For example, Kai Nielsen, in his Ethics without God (Amherst, NY: Prometheus, 1990), ch. 7, presents Hobbes as developing one of the two main ways in which a secular humanist might try to make sense of morality.

4. A. E. Taylor, "The Ethical Doctrine of Hobbes," Philosophy 13 (1938), 406-24. I have let the text stand as I originally wrote it. But in the interim I have learned from Paul Cooke that John Hunt anticipated Taylor in his Religious Thought in England, published in 1870. See Cooke's Hobbes and Christianity (Lanham, MD: Rowman \& Littlefield, 1996), p. 22.

5. Howard Warrender, The Political Philosophy of Hobbes (Oxford: Clarendon Press, 1957); F. C. Hood, The Divine Politics of Thomas Hobbes (Oxford: Clarendon Press, 1964).

6. David Gauthier, The Logic of Leviathan (Oxford: Clarendon Press, 1969).

7. Jean Hampton, Hobbes and the Social Contract Tradition (Cambridge: Cambridge University Press, 1986). Unlike Gauthier, Hampton never raises the issue of Hobbes' theism in a way which suggests that she considers the hypothesis of his atheism to be worthy even of consideration. She writes as if his theism were a settled matter and holds that the way to rebut Taylor and Warrender is to show how Hobbes gets from his psychological assumptions to his moral and political conclusions.

8. Gregory S. Kavka, Hobbesian Moral and Political Theory (Princeton: Princeton University Press, 1986). See particularly pp. 361-3.

9. A. P. Martinich, The Two Gods of Leviathan (Cambridge: Cambridge University Press, 1992); Sharon Lloyd, Ideals as Interests in Hobbes' Leviathan (Cambridge: Cambridge University Press, 1992).

10. That's her view on pp. 112 and 345-6 of ldeals as Interests, at least. But cf. p. 17.

11. Ibid. See particularly pp. $272-4$ and 278 .

12. Not to paint too bleak a picture of isolation: Raymond Polin, Hobbes, Dieu et les hommes (Paris: Presses Universitaires de France, 1981), David Johnston, The Rhetoric of Leviathan (Princeton: Princeton University Press, 1986), and David Berman, A History of Atheism in Britain: From Hobbes to Russell (London: Croom Helm, 1988), have all published views which at least tend to question Hobbes' religious commitments. Quentin Skinner's recent book, Reason and Rhetoric in the Philosophy of Hobbes (Cambridge: Cambridge University Press, 1996), pp. 13-14, dismisses the interpretations of writers like Martinich as insensitive to the irony in Hobbes' discussions of Christianity. I also find Paul Cooke's Hobbes and Christianity very congenial. 
13. Most fully in "'I Durst Not Write So Boldly" or, How to Read Hobbes' TheologicalPolitical Treatise," in Hobbes e Spinoza, Scienza e politica, ed. Daniela Bostrenghi (Naples: Bibliopolis, 1992), pp. 497-593. (Since this volume is not widely available in American libraries, I plan shortly to put a version of it on my Web site, http://www-personal.umich.edu/ emcurley.) See also the introduction and annotation to my edition of Leviathan and "Calvin and Hobbes," Journal of the History of Philosophy 34 (1996), 251-77. These pages include a reply by Martinich, and my reply to his reply.

14. Notable exceptions to this generalization are Quentin Skinner, Richard Tuck, and Johann Sommerville.

15. Kavka, Hobbesian Theory, p. xiii.

16. This seems to have been Sharon Lloyd's worry in Ideals as Interests, p. 323, n. 2.

17. See pp. lxx-lxxi in my edition of Leviathan and, for a similar anecdote (no. 12), p. lxviii. (Aubrey gives the quotation from Horace in Latin. The translation is mine.)

18. The Correspondence of Thomas Hobbes, 2 vols., ed. Noel Malcolm (Oxford: Oxford University Press, 1994), 2:913-15.

19. In the appendix of Two Gods in which he criticizes my article, "'I Durst Not Write So Boldly'...."

20. “'I Durst Not Write So Boldly' ...," p. 506.

21. Julius had a very bad press in the sixteenth century. Rabelais not only consigns him to hell (along with many of his fellow popes), he also makes him an especially pathetic creature. See The Histories of Gargantua and Pantagruel, tr. J. M. Cohen (Harmondsworth, Middlesex: Penguin, 1955), II, xxx, p. 269.

22. See The Praise of Folly and Other Writings, ed. Robert Adams (New York: Norton, 1989), p. 173. In the text I had assumed, in company with most previous students of Erasmus, that he was indeed the author of the anonymously published Julius Excluded. But a recent article by Patrick Collinson in the Times Literary Supplement (Dec. 26, 1997) alleges that Dr. Cathy Curtis has established that this work was actually written by Richard Pace. Apparently Erasmus was not pleased that its authorship was ascribed to him. I have chosen to let the text stand as it is, since I have not been able to examine Dr. Curtis' arguments.

23. Cf. The Praise of Folly, pp. 70-2, with the Letter to Martin Dorp (May 1515), defending his Folly (esp. pp. 230-4 in Adams' edition).

24. Erasmus was accused of Arianism, for rejecting, on text-critical grounds, a verse in 1 John 5:7, which was the best scriptural support for the doctrine of the Trinity. See Cornelis Augustijn, Erasmus, His Life, Works, and Influence (Toronto: University of Toronto Press, 1991), pp. 93-4. His comments on the Trinity in his treatise On the Freedom of the Will (in Luther and Erasmus: Free Will and Salvation, ed. E. Gordon Rupp and Philip S. Watson [Philadelphia: Westminster, 1969], p. 40) suggest at least a certain uneasiness about the doctrine.

25. Hobbes makes an analogous point in L vii, 7: "When we believe that the Scriptures are the word of God, having no immediate revelation from God himself, our belief, faith and trust is in the church, whose word we take." It seems fair to infer that if we take away trust in the church, we take away trust in Scripture as the word of God.

26. That it need not is the joke behind the Second Story of the First Day in Boccaccio's Decameron. Giannotto, a Christian merchant living in Paris, wished to convert his Jewish friend, Abraham, to Christianity. After much argument Abraham finally agreed to become a Christian, but only if he could first visit Rome and observe firsthand the behavior of the man whom Giannotto claimed was God's vicar on earth. Giannotto objected to this condition, thinking that if Abraham witnessed the con- 
duct of the Roman clergy, he would never accept baptism. But his argument was unavailing, and Abraham went to Rome. When he returned to Paris, he told the surprised Giannotto that he had resolved to become a Christian - not because he had not witnessed great wickedness in Rome, but because he thought that any religion which could flourish when its clergy were so corrupt must be preserved by divine providence. I do not know whether or not Hobbes read Boccaccio. But he had clearly thought about the issue Boccaccio's story raises.

27. Here I cite the translation of The Prince by Russell Price (Cambridge: Cambridge University Press, 1988), p. 40. But I have not found a translation of this work which I am consistently pleased with. Sometimes I will cite other translations. Sometimes, under the guidance of the many existing translations, I venture my own version.

28. They circulated privately among the members of a circle who met in the Oricellari Gardens, some members of which were affiliated with the Medici party. (See J. R. Hale, Machiavelli and Renaissance Italy [London: English Universities Press, 1961], pp. 168-73.)

29. The Prince does seem to have won Machiavelli some favor from the Medici. After the death of Lorenzo they invited him to advise them on the best form of government for Florence (he recommended a republican government) and later commissioned him to write his History of Florence (Sebastian de Grazia, Machiavelli in Hell [Princeton: Princeton University Press, 1989], pp. 13, 114).

30. Here I follow David Wootton's translation, in Machiavelli, Selected Political Writings (Indianapolis: Hackett, 1994), p. 118. Wootton's introduction to this edition contains the most plausible attempt I have seen to reconcile the politics of The Prince with those of The Discourses.

31. It is a nice question whether Hobbes thinks Moses is genuinely different from the other founders of commonwealths. According to $\mathrm{L}$ xii, 12, he is supposed to be. But this may be undermined by $\mathrm{xxvi}, 40-1$. Interesting here is chapter vi of The Prince. The subject is new kingdoms acquired by one's own skill (virtù). Machiavelli first lists four figures as outstanding examples: Moses, Cyrus, Romulus, and Theseus. He then says that we should not discuss ("ragionare di," so perhaps, following Mansfield, "reason about") Moses' skill, since "he was a mere agent, following the instructions given him by God." But he does proceed to 'discuss' Moses, in the course of arguing that the other founders of states did not behave any differently from Moses, "who had such a great teacher." What Moses evidently learned from God was to use force when necessary, without being deterred by the fact that he would have to kill a great many people. Romulus is reported to have killed two people to establish his authority. Moses is reported to have killed three thousand. Cf. Discourses I, ix, III, xxx, and Exodus 32:28.

32. Cf. de Grazia, Machiavelli in Hell, p. 89. For a more subtle view of Machiavelli's relation to Christianity, see Isaiah Berlin, "The Originality of Machiavelli," in Against the Current, ed. Henry Hardy (New York: Penguin, 1982), pp. 45-56. Although I think Berlin is wrong (p. 47) to take at face value the passage I quote in the next paragraph, he is surely right to say, in the end (p. 54), that Machiavelli is rejecting Christian ethics in favor of pagan morality.

33. Consider, for example, Discourses I, xxvi, where Machiavelli advises that, if we want to opt for being good, we should remain private citizens; if we want to hold political power, we must be prepared to adopt evil methods. Cf. his account of Giovampagolo Baglioni, the tyrant of Perugia, who passed up his opportunity to assassinate Julius when Julius entered Perugia with only his personal guard to protect him (and with the evident intention of removing Giovampagolo as ruler of Perugia). 
Machiavelli expresses regret that Giovampagolo did not have the courage to take advantage of his chances: "He would have won eternal fame for being the first person to show the clergy just how little one should respect people who live and govern as they do" (Discourses, I, xxvii, Wootton, pp. 132-3). Cf. also Quentin Skinner, Machiavelli (New York: Hill \& Wang, 1981), pp. 30, 38, 62-4. At the Hanover conference Barbara Tovey called my attention to a parable in Boccaccio (Decameron, I, ix), which questions whether rulers act properly when they adhere to the Christian principle which requires us not to resist evil.

34. See Luther and Calvin, On Secular Authority, ed. Harro Höpfl (Cambridge: Cambridge University Press, 1991), p. 36.

35. The Education of a Christian Prince, vol. 27 in Collected Works of Erasmus, ed. A. M. T. Levi (Toronto: University of Toronto Press, 1986), p. 217. Readers who are familiar with the life of the prince to whom this advice was given (Charles V) may judge the extent to which he followed it.

36. See Jean Bodin, Colloquium of the Seven about Secrets of the Sublime, tr. M. D. L. Kuntz (Princeton: Princeton University Press, 1975).

37. For Oldenburg's reaction see Richard Popkin, "The Dispersion of Bodin's Dialogues in England, Holland and Germany," Journal of the History of Ideas 48 (1988), 157-60, and "Could Spinoza have known Bodin's Colloquium heptaplomeres?", Philosophia, 16 (1986), 307-14. For Leibniz's reaction, see his letter to Jacob Thomasius, April 1669, in Leroy Loemker, Leibniz's Philosophical Papers and Letters (Dordrecht: Reidel, 1969), p. 102.

38. Bodin, Colloquium, pp. 343-6, 431-3.

39. In The Elements of Law Hobbes writes: "The sum of virtue is to be sociable with them that will be sociable, and formidable to them that will not" (I, xvii, 15). Not quite the Golden Rule, I think.

40. Luther, De servo arbitrio, in Rupp and Watson, Luther and Erasmus: Free Will and Salvation, p. 114.

41. In discussion at the Dartmouth conference Margaret Wilson reminded us that there is a long tradition of just war theory within Christianity, and that many authors, whose commitment to Christianity should not be questioned, have argued that the use of force is sometimes legitimate. I would not be thought to deny that. (The debates over the toleration of heretics would provide another example. Cf. Joseph Lecler, Toleration and the Reformation [London: Longman Group, 1960], bk. 1.)

But it seems to me that there is a great difference between someone like Grotius, say, for whom the Gospel teachings make any use of force profoundly problematic, requiring elaborate rationalization, and someone like Hobbes or Machiavelli, who contemplates the use of force with equanimity, provided that the end for which force is used is a sufficiently good one. But I have some sympathy with Tolstoy's view, that the Christian rationalizers of the use of force are not being true to the authentic teaching of their master. Cf. the excerpts from My Religion presented in Walter Kaufmann's Religion from Tolstoy to Camus (New York: Harper, 1961), pp. 45-66.

42. I quote the text as given in my edition of Leviathan, p. lxviii, which incorporates an emendation by V. de S. Pinto. The emendation has some importance, since it removes one reason Hood had for skepticism about Aubrey's reporting.

43. "'I Durst Not Write So Boldly' ..."

44. That this person might in fact be a woman was one ground of objection to Hobbes' erastianism. In L xlii, 78a (a passage which occurs only in the Latin Leviathan) Hobbes defends the right of the queen to be the head of the church.

45. Martin Luther, Appeal to the Ruling Class of German Nationality, in Martin Luther, 
Selections from His Writings, ed. John Dillenberger (New York: Doubleday/Anchor, 1961), pp. 417, 457.

46. Previously I cited $L$ xii, where Hobbes reminds us that, according to Livy, Numa used false claims of divine revelation to establish his authority. Also interesting is a passage in $\mathrm{L}$ vii, 7, where Hobbes writes: "If Livy say the Gods once made a cow speak, and we believe it not, we distrust not God therein, but Livy." There is a passage in Livy (III, 10) where he talks about a cow's speaking; but he does not there say that the Gods made a cow speak. He says that in one year it was believed that a cow had spoken, and that similar stories had not been believed in the preceding year. Hobbes' point is counterfactual: if Livy had reported such a miracle, believing in its occurrence, Christians could reject his claim without impiety. They would be mistrusting only a human historian.

I assume that Hobbes will accept (indeed, wishes to encourage) the obvious extension of this point: if non-Christians reject the reports of miracles in the Christian Scriptures, they are not being impious, they are just mistrusting the humans who made the reports. Later Hobbes' discussion of Scripture will emphasize that for much of Scripture we have no idea who wrote it ( $\mathrm{L}$ xxxiii). All we know is that many of the books of the Bible were not written by the people traditionally thought to be their authors. So we do not know whom we would be trusting if we believed the stories in those books.

47. I summarize here a fuller discussion of this argument in my article, "The State of Nature and Its Law in Hobbes and Spinoza," Philosophical Topics, 19 (1991), 97-117.

48. I.e., just after the Theological-Political Treatise appeared, and at a time when he was much concerned about this work of Spinoza's. See my "Homo audax: Leibniz, Oldenburg and the TTP," in Studia Leibnitiana, Supplementa, Leibniz'Auseinandersetzung mit Vorgängern und Zeitgenossen, ed. Ingrid Marchlewitiz and Albert Heinekamp (Stuttgart: Steiner, 1990), pp. 277-312.

49. Leibniz to Hobbes, July 1670, in Correspondence of Hobbes, 2:717.

50. As I note in my edition of Leviathan, Aquinas had associated the biblical Leviathan with the devil, in his The Literal Exposition on Job: A Scriptural Commentary Concerning Providence, ed. Anthony Damico, tr. Martin Jaffe (Atlanta: Scholars Press, 1989), p. 448. See also Bodin's Colloquium of the Seven, pp. 105, 110, 118, 217. It would be interesting to know whether or not Hobbes had read Bodin's Colloquium.

51. I quote Leibniz's letter to Jacob Thomasius, September 23, 1670, Akademie ed., II, i, p. 66.

52. In the phrase "men use to call," near the beginning of this quotation, the received text is correct, pace Martinich (pp. 123-4). "Use" is a present tense verb, meaning "are accustomed to"; it is not a misprint for "used" (and hence a way of forming the past tense).

53. Taylor, "Ethical Doctrine," pp. 418-20; Warrender, Political Philosophy, pp. 98-100.

54. David Gauthier pointed this out in discussion during the conference at Irvine, and Steve Darwall made the same point in his review of Martinich, Philosophical Review 103 (1994), 748-52.

55. Readers of Spinoza will recall that he argues for a similar conclusion in the Appendix to Part I of the Ethics. But he does not make that claim in the TheologicalPolitical Treatise.

56. It was, of course, one of Hobbes' first lines of defense against the charge of atheism that the only ground on which a person can legitimately be accused of atheism is if he has straightforwardly denied that God exists. Cf. Thomas Hobbes, The English 
Works of Thomas Hobbes, ed. William Molesworth, 9 vols. (London: John Bohn, 1839), 4:75-6, on "atheism by consequence." But those who are inclined to press that passage should consider also the appendix to the Latin Leviathan, ii, 36, and my annotation of that passage in the Hackett edition.

57. In “'I Durst Not Write So Boldly”...”, pp. 572-88.

58. See excerpts [3] and [5] from his Latin Autobiography, in my edition of Leviathan, pp. Ixiv - lxv.

59. See Thomas Hobbes, Critique du De mundo de Thomas White, édition critique d'un texte inédit par Jean Jacquot et Harold Whitmore Jones (Paris: Vrin-CNRS, 1973), p. 49.

60. The first public identification of the work as Hobbesian was Jacquot's "Notes on an unpublished work of Thomas Hobbes," Notes and Records of the Royal Society of London 9 (May 1952). This was followed by the critical edition of the Latin text cited in the previous note, and an English translation by Whitmore Jones, Thomas White's De mundo Examined (London: Bradford University Press, 1976).

61. David Johnston, The Rhetoric of Leviathan (Princeton: Princeton University Press, 1986).

62. Cf. Luther, De servo arbitrio, in Rupp and Watson, Luther and Erasmus: Free Will and Salvation, pp. 138, 230, 244.

63. See “'I Durst Not Write So Boldly' ... , ” pp. 574-9.

64. See Lloyd, Ideals as Interests, pp. 15-23.

65. Ibid., pp. $272-4$.

66. She does not discuss any of my work on Hobbes, of course. None of it was in print at the time she was writing, so she had no reason to be aware of it. But she does discuss the similar views of David Johnston.

67. Ibid., p. 273.

68. Many committed Christians did, of course, think their religion was under attack, and did, as Lloyd knows, leap to its defense. She suggests that some (perhaps many) of the contemporary accusations of atheism were just abusive name calling and did not reflect an authentic assessment of Hobbes' position (p. 273). Martinich takes a similar line. No doubt the motivations of Hobbes' critics are complex and sometimes obscure. But I think the outrage of critics like Clarendon was genuine and shows a perceptive reading of Hobbes. See Edward Hyde (Lord Clarendon), A Brief View and Survey of the dangerous and pernicious Errors to Church and State, in Mr. Hobbes's Book Entitled Leviathan (Oxford, 1676).

69. See the final chapter of Part III, and particularly xliii, 3-5, 11. It helps Hobbes' case greatly that he can treat those troublesome imperatives from the Sermon on the Mount as merely counsel, not command; hence, not law; hence, not binding. Cf. xliii, 5 , with xxv, 10-11, and the annotation there. The status of these imperatives was a major issue in the Reformation, with the leading reformers insisting that they were commands, and the Catholic Church replying that they were merely counsel. $\mathrm{Cf}$. Calvin, Institutes, pp. 29-30, and 249 in the Battles translation of the 1536 edition.

70. See, for example, M. A. Screech's introduction to his edition of Montaigne, The Complete Essays (New York: Penguin, 1991), or his Montaigne and Melancholy (Penguin, 1991). This was also the view advocated by Screech's predecessor as a translator of Montaigne, Donald Frame, in "Did Montaigne Betray Sebond?" Romantic Review 38 (1947), 297-329.

71. For Pascal on Montaigne, see $\$ \S 780,680$, and 649 in the Penguin edition of the Pensées, ed. by Krailsheimer ( $\$ \$ 62,63$, and 65 in the Everyman edition). For a defense of reading Montaigne as an atheist, see D. L. Schaefer, The Political Philosophy of 
Montaigne (Ithaca: Cornell University Press, 1990). Those who think it must be anachronistic to question the religious convictions of any author in this period should read the following works by David Wootton: "Lucien Febvre and the Problem of Unbelief in the Early Modem Period," Journal of Modern History 60 (1988): 695-730; "New Histories of Atheism," in Atheism from the Reformation to the Enlightenment, ed. Michael Hunter and David Wootton (Oxford: Clarendon Press, 1992); and Paolo Sarpi (Cambridge: Cambridge University Press, 1983). In Montaigne's case one thing which persuades me is that the professed fideism of the "Apology for Raymond Sebond" is of the strong, antirationalist kind, which proclaims the Christian faith to be, not merely beyond, but contrary to reason.

72. Of course, we might not need the Reformation to get this line of questioning going. Barbara Tovey pointed out to me that there is a version of it in Boccaccio's Parable of the three rings (Decameron, First Day, Third Story). But the Reformation made the issue more urgent.

73. I simplify considerably here. For a more complex and accurate presentation of the argument see chapter 8 of Ian Hacking's The Emergence of Probability (Cambridge: Cambridge University Press, 1975). Hacking's article is also included in Gambling with God, ed. Jeff Jordan (Lanham, MD: Rowman \& Littlefield, 1994), which contains a number of interesting articles on the wager. See particularly: Edward McClennen, "Pascal's Wager and Finite Decision Theory," and Roy Sorensen, "Infinite Decision Theory."

74. I think Pascal is widely assumed to have argued in this way. Cf. the anecdote about John von Neumann, Gambling with God, p. 1. The infinite disutility of failing to believe in God in case God does exist is part of the version of the wager argument which appears in the Port Royal Logic, as McClennen notes, Gambling with God, p. 133.

75. As with Pascal I simplify considerably, focusing on the prima facie hardest case for Hobbes: covenant breaking in the state of nature by an atheist. Hobbes also replies in this passage to theists in civil society who think breach of faith with their sovereign may earn them eternal felicity in heaven. To them Hobbes replies, that they cannot rationally act on that belief, since we can have no natural knowledge of man's estate after death. This implicitly denies that revelation can be a ground of rational belief and action.

76. So I do think Hobbes recognizes obligations in the state of nature, though I think that they cannot be obligations in quite the usual sense of that term. Earlier I spoke of Hobbes' laws of nature as being a "special kind of hypothetical imperative." My thought (which goes back to Watkins) is this: normally when we speak of a hypothetical imperative we have in mind a conditional whose antecedent is contingent. But Hobbes' laws of nature are conditionals which have the form "If you want to preserve yourself, then do X." And he assumes that the desire for self-preservation is both natural and necessary.

It may be objected that we do not always choose to preserve ourselves when faced with a life-or-death situation. (This is an objection which Jean Hampton made in the discussion in Irvine, and which Bernard Gert made in the discussion in Hanover; presumably it is also an objection Sharon Lloyd would make. There is a nice summary of the conflicting evidence in Greg Kavka's book, in the section on Death Avoidance.) I think the best way to understand Hobbes may be to construe him as holding that we (must) always desire to avoid death, though that may not always be our strongest desire. The desire to avoid shame, for example, or to avoid excruciating pain, may override it. Whether such a position would be sufficient to account for the force of these imperatives is a matter I leave to be decided later. 
77. It seems to me that this comes out somewhat more clearly in the Latin version of the argument than in the English. Cf. my edition, p. 91, n. 6, p. 92, n. 8.

78. I do not suppose he thinks, as Pascal presumably would regarding hell, that the disutility is infinite. Whether it makes sense to admit infinite utilities is a matter of controversy among decision theorists (cf. the articles by McClennon and Sorenson cited earlier), but it seems desirable to avoid them if possible.

79. Kavka, Hobbesian Moral and Political Theory, pp. 137-44.

80. Or even, I think, in maximizing expected utility, though Kavka holds that out as one possible interpretation of the reply to the Fool. I think Hobbes was too skeptical about the possibility of attaching any precise values to the probabilities of other people's actions to rely on expected utility maximization as a conception of rationality. 